\title{
Fiscal Determinants of Empowerment
}

\author{
Uri Raich
}

\begin{abstract}
Empowerment of local governments and citizens is a primary object of decentralization. Using the analytic lens of empowerment, this paper explores the nature of decentralized governance and how this type of structure is likely to be more or less empowering. The primary concern of this work is fiscal decentralization, specifically the association between fiscal determinants and the degree of empowerment of both citizens and local governments.

The paper's main argument is that both the revenue and expenditure characteristics of local public finances have an effect on the degree of empowerment. The hypothesis is that in a context of decentralized local governance, empowerment is most likely to occur when three conditions prevail: low costs of participation; large and flexible budgets; and a high proportion of tax revenues from a local base. However, these ingredients for empowerment will not necessarily produce outcomes that are progressive and pro-poor. This paper contrasts the intrinsic and the instrumental approaches to empowerment, but it does not assess the impact of empowerment on instrumental outcomes. For this hypothesis to support an instrumentalist perspective on empowerment, further empirical work must be conducted.
\end{abstract}

\section{World Bank Policy Research Working Paper 3705, September 2005}

The Policy Research Working Paper Series disseminates the findings of work in progress to encourage the exchange of ideas about development issues. An objective of the series is to get the findings out quickly, even if the presentations are less than fully polished. The papers carry the names of the authors and should be cited accordingly. The findings, interpretations, and conclusions expressed in this paper are entirely those of the authors. They do not necessarily represent the view of the World Bank, its Executive Directors, or the countries they represent. Policy Research Working Papers are available online at http://econ.worldbank.org. 


\section{Table of Contents}

Acknowledgements . $\mathrm{i}$

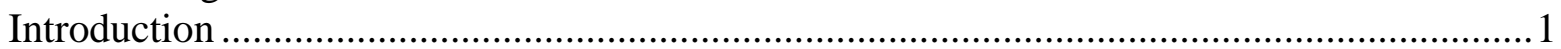

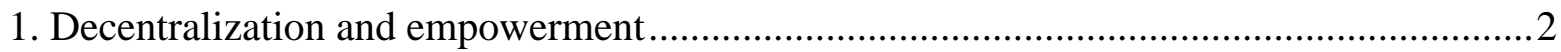

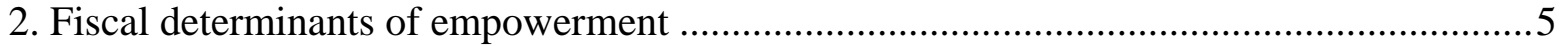

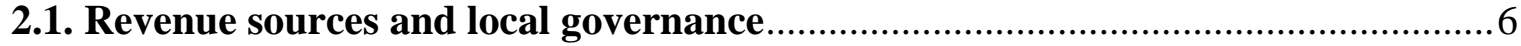

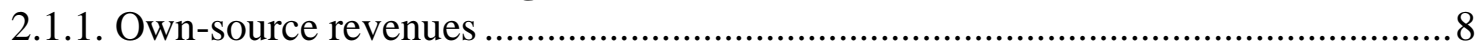

2.1.2. Intergovernmental transfers....................................................................... 10

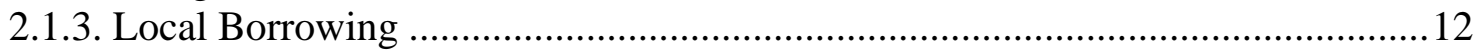

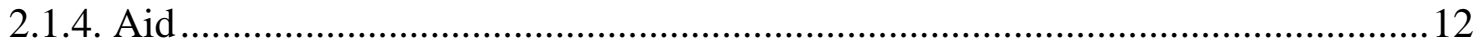

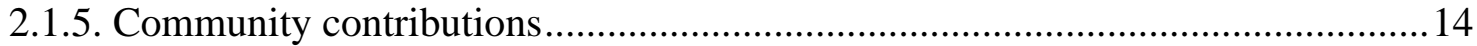

2.2. Budget characteristics and local governance ............................................... 14

2.2.1. Budget Size ..................................................................................... 14

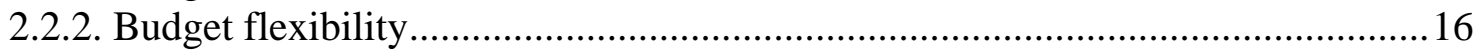

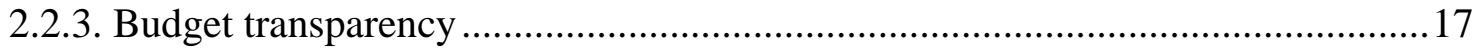

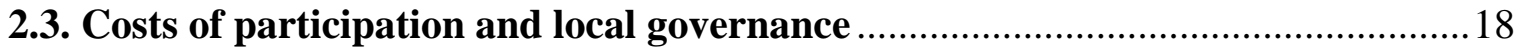

3. Impacts of decentralization on the distribution of power at the local level .....................20

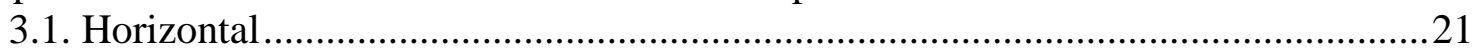

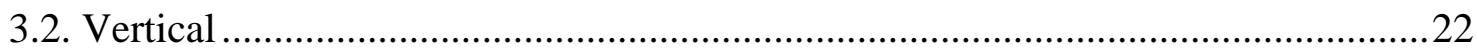

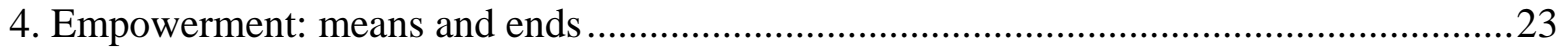

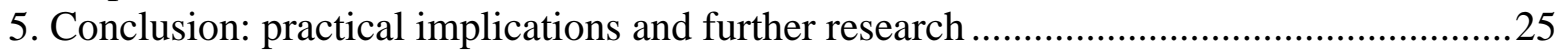

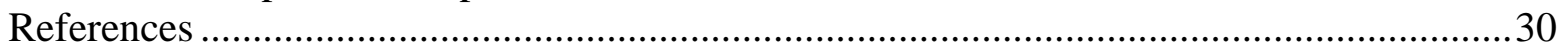

\section{Boxes}

Box 1: Tax coercion and voluntary compliance..........................................................

Box 2. Basics of intergovernmental transfer design .................................................... 11

Box 3. Problems in a multi-actor context: The case of Nepal...........................................13

Box 4. Budget size and local participation: Participatory Budget in two Brazilian cities .....15

Box 5. Institutional design for intergovernmental fiscal relations ...................................23

Box 6. Problems with local revenues in India.........................................................26

\section{Figures}

Figure 1. Empowerment: institutions and actors....................................................... Figure 2. Local accountability and effectiveness in state-citizen engagement by source of

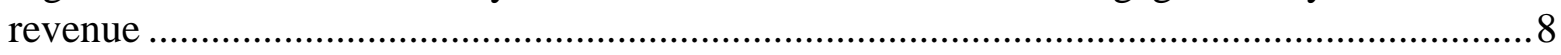

\section{Tables}

Table 1. Total Budget Expenditure in Soums and Aimags (percent) .................................17

\section{Annexes}

Annex 1. Case Study: Starving Good Governance to feed the Needy .35 


\section{Acknowledgements}

The preparation of this paper benefited from the support and contribution of various colleagues. The paper was prepared as part of the local governance work of the Empowerment Team in the Poverty Unit of PREM. It builds on the framework developed by that team for understanding and operationalizing empowerment. I am particularly grateful to the team leader, Ruth Alsop for her guidance and inputs to the paper. Also, I would like to recognize the valuable and supportive contributions of my other colleagues - Abigail Somma for her clarity of thought and considerable editorial skills and Jeremy Holland for his insights and commentary. I also owe thanks to Sudhir Shetty and Luca Barbone for their interest in this topic. Finally, I am in debt to the peer reviewers Jonathan Fox (Woodrow Wilson Center) Victor Vergara, and Deborah Wetzel, as well as Malcom Smart (DFID), who all provided constructive and thoughtful comments on substance, focus, and presentation of the paper. All errors and omissions are mine. 


\section{Introduction}

Decentralization and empowerment have emerged as key concepts in development debates. Still, little is known about the role that local public finances play in the process of empowering citizens and local governments. "Local governments" are here defined as the lowest level of territorial organization with political and fiscal powers. This definition encompasses both elected politicians and the local administrative cadre. ${ }^{1}$

This paper analyzes how local fiscal conditions associate with -and help stimulate- differing degrees of empowerment; that is, it explores whether an opportunity to make choices about local governance exist, whether people use those opportunities, and -if they use the opportunity- whether they achieve desired outcomes (Alsop and Heinsohn, 2005). The paper explores these relations both within local governments (elected and administrative) as well as among citizens, local, and upper tiers of government. It argues that from a public finance perspective, there are three determinants that influence the capacity of citizens and local governments to make effective choices: (i) the source of local revenues; (ii) the size and flexibility of local budgets, and (iii) the costs to individuals of participating in the mechanisms and processes of state-citizen engagement. ${ }^{2}$

- Revenue

The paper explores whether the source of local finances (own-source revenues, transfers, aid, debt, and community contributions) has any effect on the level of vertical accountability of local governments to both citizens and upper tiers of government, in relation to both budget allocation and service delivery.

\section{- Expenditure}

In a decentralized context, participatory budgeting has become one of the principal mechanisms through which citizens engage with local governments. ${ }^{3}$ This paper explores how the size and flexibility of budgets affect the level and effectiveness of citizen participation over the allocation of local budgets.

\section{- Costs to local citizens of choosing to participate in local governance mechanisms and processes}

Local participation is often seen as a normative process that assumes an inherent desire of citizens to engage in all public decisions that affect their lives. However, this view

\footnotetext{
${ }^{1}$ The decentralization literature seldom distinguishes the very diverse types of local governments that vary from large and powerful middle-tiers to small rural communities. This is problematic insofar as decentralization reforms may empower some local governments but not others -especially regarding fiscal and budgetary autonomy. This paper deals with this issue by focusing on the lowest territorial unit with political (democratic rights) and fiscal (revenue and expenditure autonomy) powers.

${ }^{2}$ The importance of these determinants is context specific, and in some cases there are other factors (i.e. political economy, social, history) that could be more critical to explain the empowerment of citizens and local governments.

${ }^{3}$ See for example the World Bank Institute project on Civic Participation in Sub-National Budgeting conducted in a number of countries in Africa, South Asia, and Latin America (http://vle.worldbank.org) and the International Budget Project of the Center of Budget and Policy Priorities that explores issues of participation and poverty reduction in 36 countries (http://www.internationalbudget.org).
} 
overlooks constraints to local participation. These constraints include measurable costs such as the opportunity costs to labor, indirect costs related to information asymmetries, and the social costs arising from low status of groups and individuals.

Based on these three factors, I hypothesize that empowerment is most likely when three conditions prevail: (i) a high proportion of own-source revenues -out of total revenues, (ii) a high proportion of budgets over which local governments have control, and (iii) low costs of choosing to participate.

This paper is organized as follows. Section one introduces the concepts of decentralization and empowerment, and explains how they relate to each other in a context of decentralized governance. Section two analyzes the impact of the local fiscal conditions on the degree of empowerment focusing on three different factors: (i) the relationship between revenues and empowerment, from the point of view of accountability; (ii) the effect of the size and composition of the local budgets on citizens' choice to participate in local decision-making; and (iii) the extent to which the costs of participation have an influence on the degree of empowerment. Section three explores the tensions among elected representatives and administrators at the local level and at the challenges of aligning national development priorities with local spending needs. Section four contrasts the intrinsic and instrumental visions of empowerment. Section five discusses some practical implications of change in local fiscal conditions on the degree of empowerment of citizens and local government.

\section{Decentralization and empowerment}

A basic rationale for decentralization is that devolving decision making power and responsibilities increases citizens' engagement in local governance decisions and makes local governments more efficient and accountable. This implies that decentralization shifts power to citizens and local governments (elected and administrative) thereby enhancing their capacities to make effective choices -that is, to translate their choices into desired actions and outcomes. ${ }^{4}$ However, the extent to which decentralization empowers citizens and local governments depends both on the type of decentralization being pursued, and on the assets and institutions that prevail at the local level.

According to the empowerment framework, the capacity of an individual or group to make effective choices is primarily influenced by two sets of inter-related factors: agency and opportunity structure.

- Agency is defined as an actor's ability to make meaningful choices -that is, the actor is able to envisage and purposively choose options. It can be measured by the availability of asset endowments, which include psychological, informational, organizational, material, social, human, and financial factors.

\footnotetext{
${ }^{4}$ The study of economic and social domains of empowerment is beyond the scope of this paper. However, notice that impacts on political/citizen empowerment may have positive externalities in other domains or may be undermined by disempowering practices in other domains (See Alsop and Heinsohn 2005).
} 
- Opportunity structure is defined as the formal and informal institutional context in which actors operate. These formal and informal rules and norms largely determine the actor's ability to transform agency into effective action.

As Figure 1 illustrates, working together, agency and opportunity structure give rise to three different degrees of empowerment, which are measured by: (i) the presence of opportunity to make a choice; (ii) whether or not an individual or group actually uses the opportunity to choose either directly -through participation- or indirectly -through representation; and (iii) if they do, whether the choice is transformed into desired outcomes (Alsop and Heinsohn, 2005).

Figure 1. Empowerment: institutions and actors

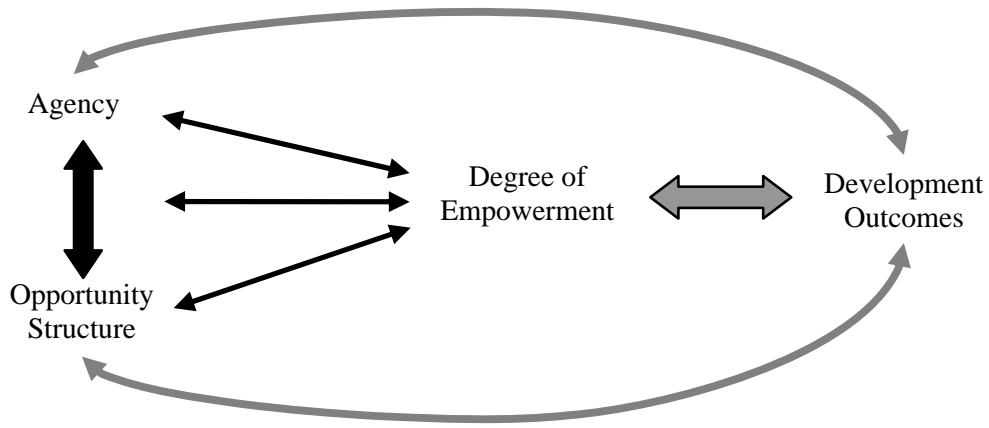

Source: Alsop and Heinsohn, 2005.

The degree of empowerment that different local actors (i.e. elected representatives, administrative bodies and citizens) achieve also depends on the type of decentralization being pursued. Decentralization is not a uniform process, but rather one that involves devolution of distinct decision-making powers and responsibilities to subnational units. Three types of decentralization are recognized (Shah and Thompson 2004):

- Political decentralization implies directly elected local governments who are accountable to citizens. It supports democratization by giving citizens, or their representatives, more influence in the formulation and implementation of policies.

- Administrative decentralization empowers elected local governments to hire and fire local staff (thereby making local officials accountable to elected officials) without any need for consultation with higher-level governments.

- Fiscal decentralization entails the responsibilities of local revenue raising and allocation. It ensures that elected officials are careful in their spending decisions as they face the possibility of being voted out. ${ }^{5}$

Decentralization affects the degree of empowerment at the local level, both by giving citizens the opportunity to engage with and hold their local governments accountable, and

\footnotetext{
${ }^{5}$ More technically, fiscal decentralization seeks to optimize social welfare by allocating resources across tiers of government according to three criteria: economic stability, allocative efficiency, and distributive equity.
} 
by granting local elected representatives power over their constituencies with relative independence from the upper tiers of government. For example, free elections and full political rights allow citizens to punish or reward governments’ performance. Similarly, devolution of fiscal powers over tax bases and rates gives local governments control over their own revenues to provide services according to local preferences. In addition to these two benefits, clear separation between local elected representatives and administrative civil servants helps citizens identify who is responsible for spending the public budget.

All the three forms of decentralization can empower citizens and local governments. However, the degree to which this is accomplished is determined by political economy and partisan factors. The existence of electoral systems and democratic institutions at the local level, for example, may raise citizen's voice, but the effectiveness of such voice depends on political factors beyond citizen's control. In terms of representative democracy, citizens may be able to vote, but they are often forced to accept the agendas set by political parties. Concerning more direct mechanisms of democratic governance, citizens may have the right to engage in local public affairs, but revenue and expenditure decisions are taken and implemented by local governments. Similarly, in the case of fiscal decentralization, local governments may have the right to raise more revenue, and thus have more power to meet citizen's needs, but may opt to not do so to avoid the political costs of taxation. Concerning administrative decentralization, this is also mediated by a number of political factors as elected local governments and administrative civil servants may have different political alignments and may be pushing for different political agendas. All these political factors are inherent to the decentralization process and affect the empowerment of citizens and local governments.

Research on decentralization has rarely directly looked at empowerment effects as manifested in citizens or local government's capacity to make effective choice. Instead most rigorous empirical analysis has focused on accountability as a critical dimension of empowerment. For this reason, the analysis in this paper references evidence of "accountability", using it as a proxy for "empowerment," but acknowledging that building accountable relationships in a decentralized context is a necessary but not sufficient condition to make effective choices.

Decentralized governance facilitates and requires the creation of accountability mechanisms within local governments -between elected officials and local administrators- and among local governments, citizens, and the upper tiers of government. The former is horizontal accountability that ensures local civil servants report to elected bodies. The latter is vertical accountability, either from local to higher tiers of government (upward accountability), or from local governments to citizens (downward, local or direct accountability). Downward accountability may also occur between citizens and service providers -who are often the local administrators. ${ }^{6}$ Upward accountability includes monitoring and evaluation mechanisms. Downward accountability includes mechanisms as diverse as the electoral system to vote out or reward politicians to other more direct mechanisms of citizen

\footnotetext{
${ }^{6}$ Local administrators may not always provide services directly, but chose to contract out the provision to the private sector. When public services are privately provided, downward accountability may change depending on weather local governments or private providers remain "responsible" for the provision.
} 
engagement, like public planning meetings, participatory budgeting, report cards and user satisfaction surveys.

Despite these many ways to promote accountability, empowerment of citizens and local governments is seldom fully realized because decentralization is often incomplete. This occurs either because central governments are reluctant to fully decentralize or because government employees resist giving up their career opportunities at the national level (Blair 2000). As a result, field officers maintain strong links with their original line ministries, thereby enjoying some insulation against local control. Hence, local administrators are not fully accountable to elected representatives, who in turn are not always accountable to the citizenry. In these cases, local governments continue to report to upper tiers of government, which partially remain in control of their political, administrative, and financial conditions. For example, when local finances are too centralized and budgets mostly consist of national revenue sources, local governments are more responsive to the upper tiers of government than to citizens' needs. In practice, this reduces the capacity of both citizens and local electoral representatives to make effective choices.

\section{Fiscal determinants of empowerment}

Decentralization entails a downward shift of authority and resources from central to subnational governments; thus, local governments increase their revenue sources and expenditure responsibilities. In developing countries, subnational revenues as percentage of GDP more than doubled from 2.3 percent in 1980 to 5.5 percent in 1999 . Similarly, subnational expenditures as percentage of GDP doubled from 3 percent in 1980 to 6.1 percent in 1997 (Shah 2004). In decentralized governments, control over the use of resources also shifts from central governments to citizens and voters, who are the ultimate users of goods and services. In the past, local governments could attribute their inability to deliver services to weak fiscal conditions, but now that they have access to more -yet limited-revenue sources, citizens turn to them for an efficient and responsible management of public resources.

In this new context of local responsibility, accountability is crucial for effective choice. If citizens are to ensure proper use of public resources, they need the means to hold local governments accountable. Studies on local governance have gone a long way to explain how citizens engage with and hold their governments accountable (Ackerman 2004) and how the process and mechanisms for state-citizen interaction function (Alsop and Kurey 2004). However, these studies have not yet systematically looked at the impact that local public finances have on these state-citizen interaction, and more generally at the distribution of power at the local level.

Although not abundant, there are a number of studies on the matter. Of the three factors explored in this paper (revenues, expenditures, and costs), local public expenditures have received most attention, but here studies have mainly focused on the processes and mechanisms by which local governments are held accountable for expenditure-related activities, such as participatory budgeting, score cards, and parent associations (Ackerman 2004). Unlike expenditures, local revenues and the costs of engagement have been given 
less attention. There are some studies on the role that revenues play in generating statecitizen engagement, but these focus on national, rather than on local level analysis (Guyer 1992, Hansohm et al. 2002, and Moore 1998). Responding to this dearth of systematic analysis of the fiscal determinants of empowerment in local governance, the next three sections propose ways to link the conditions of the local public finances with the capacity of citizens and local governments to make effective choices.

\subsection{Revenue sources and local governance}

Presently "there is no general theoretical or conceptual framework about the connections between state income sources and state-society relations” (Moore 1998: 90). ${ }^{7}$ However, various studies claim that local revenue generation is positively associated with the establishment of accountable and responsible state-citizen relations (e.g. Jones and Stuart 1983, and IADB 1994). The basis of this claim is that the source or origin of local revenues is important because local governments treat revenue from different sources in different ways. This is that local governments spend a dollar raised through taxes differently from a dollar they received through some other means, like international aid or intergovernmental transfers. This origin-base criterion assumes that accountability derives from the source where the revenue originates. Thus, the more capacity local governments have to extract revenue from their own tax bases, the greater their accountability to citizens. Conversely, the more fiscally dependent on other non-local sources of revenue, the less locally accountable to citizens they would be. The focus of this origin-base criterion is on downward accountability from local governments to citizens, as the local level is where the most intense state-citizen engagement takes place and where citizens experience the highest levels of political representation. ${ }^{8}$

The idea that local governments are more accountable to citizens when relying on their own tax bases has been articulated in a number of political and economic debates on decentralization and local public finances (e.g. Merat 2004). The rationale is that local governments are more responsible and accountable when they tax and spend independently. By levying taxes, and letting local jurisdictions bear the tax burden at the margin, the budgetary actions of local governments are guided by tax-benefit considerations and economic efficiency improves (Norregaard 1997).Conversely, accountability blurs when "separating the pleasure of expenditure benefits from the pain of taxation” (Bahl and

\footnotetext{
${ }^{7}$ There are various reasons for the absence of revenue consideration in local governance literature. Moore and Rakner (2002) argue that fiscal policy is not always seen as belonging to the public domain, but rather to a technical arena restricted to the influence of economic and political elites. According to their argument, "insofar as there has been a politics of taxation, it often has been narrow, specialized, and concentrated in nonpublic spaces. It has been the politics of small pressure groups lobbying [...] ministers and tax officials about their tax liabilities for the current year.” Additionally, Guyer (1992), in a study on Nigeria, notes that there is not much discussions on public revenue in the governance literature in poor countries. He attributes this to the lack of emphasis on taxation at a time when the image of Africa is one of poverty.

${ }^{8}$ In terms of electoral politics, due to the different number of voters at each tier of government, a local citizen has a higher probability to influence a local than a national representative. For example, if a local jurisdiction has 1,000 voters, a single individual vote will have a weight of 0.001 . A national jurisdiction (i.e. electoral district), however, would have a larger voter population - lets say 10,000 - so the weight of an individual vote would be lower - in this case, 0.0001 . The weight of these individual voters can be interpreted as simple probabilities of citizens influencing their representatives.
} 
Schroeder 1983: 116). Therefore, according to the IADB (1994: 180), local governments must raise their own revenues, because "if they do not, the whole rationale for improved economic efficiency and enhanced governance is in jeopardy.” Jones and Stuart (1983: 94) summarize the claim in favor of local revenue generation in the following way:

To achieve genuine local accountability, the local government financial system should ensure that local authorities draw the buck of their income from their own local taxpayers and voters, and that the latter are aware that they are paying their taxes to support local government services.

Despite these claims, it is not clear how the relationship between revenue sources and the level of local accountability plays out. Actually, other researchers argue that the link between local revenue generation and accountability is highly contested. This is particularly true because local governments are always reliant, at least to some degree, on intergovernmental transfers and other non-local sources of revenue (Gloppen and Rakner 2002, Devas 2002). In order to explain this relationship, Moore (1998) developed the concept of "earned" income. Such concept proposes that income is "earned" according to the level of effort states exert in working with citizens. States earn income to the extent that they (i) deploy an extensive organization to collect it, and (ii) provide reciprocal services to citizens. The more a state earns its income through a bureaucratic apparatus for tax collection, the more it needs to enter into reciprocal agreements with citizens about provision of services and representation -in exchange for tax contributions. The greater the dependence of governments on "earned" income, the more likely state-citizen relations are to be characterized by accountability and responsiveness.

Moore applies the concept of "earned income" at the national level, but there is no reason why it cannot be used at the local level. In fact, Fjeldstat (2002) argues that since local authorities interact more closely with citizens than other organs of the state apparatus, local government revenues may be considered a more relevant testing ground of the concept of "earned income" than the central government. ${ }^{9}$ Traditionally, local public finance identifies three main sources of local revenues:

- own-source revenues

- intergovernmental transfers

- local borrowing.

In addition, local governments in poor countries have two other sources of revenue: ${ }^{10}$

- international aid, and

- locally generated community contributions.

\footnotetext{
${ }^{9}$ One potential problem with establishing a link between accountability and "earned income" at the local level in developing countries is that the number of payers of property taxes -the main local tax-is usually limited. Therefore, the argument fails to account for all those citizens that do not contribute to the financing of local public services, but that benefit from their provision.

${ }^{10}$ These two additional sources of local revenue do not commonly form part of local budgets, so they are often excluded from studies on local public finances.
} 
Figure 2 maps each of these sources of revenue along a continuum of effective and locally accountable state-citizen relationships. Concerning accountability, the figure places the sources of revenue along an axis of "local" accountability between local governments and citizens. This placement does not capture other accountability relations either within local governments (horizontal accountability) or between local and upper tiers of governments (upward accountability). In terms of effectiveness, the placement in this figure refers to the capacity of citizens to engage with local governments and to the power that citizens have to hold them accountable for the use of each revenue source. This notion of effectiveness takes into account both how effectively citizens channel their preferences to local governments, and how effectively local governments respond to these preferences -as opposed to the preferences of central governments or external donors. This notion of effectiveness is not a measure of how effectively local governments use their different types of resources; local governments can spend any revenue source effectively or ineffectively. This chart is not definitive as much depends on the specific characteristics (design and implementation) of the revenue sources and on the conditions in which they reach the local level, but it provides a useful starting point.

Figure 2. Local accountability and effectiveness in state-citizen engagement by source of revenue

\begin{tabular}{|c|c|c|}
\hline Contributions & Transfers & Borrowing \\
\hline High Effective State-Citizen Engagement/ & & Low Effective State-Citizen Engagement/ \\
\hline High Local Accountability & & Low Local Accountability \\
\hline
\end{tabular}

2.1.1. Own-source revenues: In developing countries, local own-source revenues are commonly limited to a few local taxes - mainly property taxes- and user fees. Because there is a strong link between taxes paid and benefits received, own-source revenues provide for the most effective and accountable type of state-citizen engagement. This association between own-source revenues and accountability is dual. A high reliance on own-source revenues promotes accountability, but having high levels of accountability also make citizens more willing to pay for services. When there are effective mechanisms for statecitizen interaction in place, citizens can better transmit their preferences to local governments and local governments can better respond to those preferences. This interaction produces two results: local governments provide more relevant and quality services, and -in turn- own-source revenues increase as citizens are more willing to pay for the services received.

For this mutually reinforcing relationship between accountability and own-source revenue to hold, the systems of local revenue generation must operate in a transparent fashion. Most importantly, citizens must trust their local tax administrators. Lack of transparency and distrust between citizens and local governments prevent service providers to respond to the citizen's preferences with relevant and quality services, and in turn citizens are unwilling to pay for the (sub-optimal) services they receive. Nevertheless, in developing countries lack of 
transparency and tax coercion, rather than trust and accountability, often mediate the relationship between citizens and local governments (Box 1).

\section{Box 1: Tax coercion and voluntary compliance}

The way governments tax their citizens is fundamental to establishing strong state-citizen relations. Much of the literature on tax compliance examines the determinants that encourage paying or evading taxes. According to the literature, norms and societal institutions (rather than pure economic determinants) stimulate tax compliance. For this Alm and Martinez-Vazquez (2001:10) argue that "it should not come as a surprise to many government officials in developing and transitional countries that controlling tax evasion will require improving overall governance and delivering value for money to taxpayers-citizens.”

However, local authorities in developing countries often view taxation too narrowly, and conceive it as an extractive instrument of the state, rather than as a way to build permanent links between the state and its citizens. The works of Fjeldstad (2002) and Luoga (2002) on local taxation in Tanzania illustrate how taxpayers feel exploited and dissatisfied with service delivery when taxes are levied in an arbitrary and coercive manner. This undermines the legitimacy of local governments and increases tax resistance. Tax coercion is clearly at odds with local accountability, as it promotes the use of non-voluntary and extortive mechanisms of tax enforcement. According to Fjeldstad (2002: 23) "the use of coercion in raising local government taxes in Tanzania is so pronounced and detested that this mode of earning income is not conducive to improving accountability of state to society.”

The use of coercion as a way to enforce compliance is commonly justified by the legal prevision that it is the duty of citizens to contribute to the maintenance of the state's general welfare. However, the use of tax coercion has various problems not only because it has negative effects on state-citizen relations, but also for purely economic reasons. Hood (1986), for example, argues that a system of coercion is not free, rather it is quite expensive. In certain settings, its costs are higher than the additional revenue that it could bring. Additionally, the argument that coercion serves as an efficient deterrent mechanism to avoid evasion, still lacks empirical support. Although it is argued that tax evaders are more likely to cooperate with authorities when they expect to be punished, evidence is not yet conclusive (Keenan and Dean 1980).

Instead of using coercive powers, states may attempt to socialize the population on the concept of fairness to stimulate tax compliance (Levi 1988). States may invoke a moral commitment, as well as the values and beliefs of constituents to support compliance. The problem with this rationale is that in certain contexts, -as in highly corrupt societies- morale may not be conducive to promote compliance, but actually may inhibit it. In these cases, Levi (1988) argues that what is needed to increase taxation without harming state-citizens relations is a system of quasi-voluntary compliance; that is one in which citizens choose to pay taxes voluntary, but in which coercion is used against those who don't comply. Similarly, Margolis (1991) argues for a system of incomplete coercion (which he refers to as "NSNX" -Neither Selfish Nor Exploited) on the grounds that (i) no society can function well if citizens routinely cheat when not being observed, and (ii) no society can rely entirely upon voluntary compliance. Ideally, local governance should promote systems of voluntary or quasi-voluntary compliance, as it is clear that taxation will not enhance state-citizen relations if citizens dislike the methods employed for raising revenue (Luoga 2002).

One additional factor for the relationship between local accountability and own-source revenue to hold, is that local authorities have control over their tax sources. At an extreme, Bird (2000) argues that a completely subnational tax might be defined as: a tax that is assessed by subnational governments, at rates decided by subnational governments, collected by subnational governments, and with proceeds accruing to subnational governments. Because developing countries have difficulties in meeting all these conditions, Bird and Vaillancourt (1998) suggest that at minimum, local governments must have control over tax rates and bases. Thus, they developed the notion of "accountability at the margin" according to which subnational governments' responsibility, depend on the capacity to 
increase or decrease their own revenues at the margin. Only when public officials have the capacity to change the tax bases and rates, then can be fully responsible and accountable for their actions.

Both for technical and political reasons, local governments seldom control their tax bases and rates, but when they do local taxation becomes the preferred way to enhance effectiveness and accountability from local governments to citizens. Citizens know that they alone will bear the costs and benefits of fiscal decisions made by local public officials; hence it is in their interest to hold officials accountable. For this reason Ahmad (1997:1) argues that "the own-revenues of lower levels of government form the most transparent source of financing, together with the greatest accountability of the providers of public services to local beneficiaries.” Despite the positive association between own-source revenues and high levels of effective and accountable state-citizen interactions, two elements should be noticed:

(i) Local control over tax rates and bases in developing countries is the exception rather than the norm. In some countries, including China, Indonesia, Brazil, Bolivia, Guatemala, Nicaragua, Peru, Nigeria, and Pakistan, upper tiers of government intervene -to various degrees- in the administration of property taxes (Shah and Thompson 2004 and WBI 2003). In other cases, like Mexico local governments have control over their local taxes -like setting the tax rates within a certain level- but because of their limited technical capacity, the upper tiers of government intervene in the administration of local taxes. In other countries, like Hungary, local governments also have control over their tax bases and rates, but they set local rates far bellow the maximum allowable rate (Garzon 2004), and

(ii) Despite the suitability of the property tax as a local source of revenue (mainly because its base is immobile), its overall collection is quite low, representing about 0.42 percent of GDP and about 2 percent of total tax revenue in developing countries (Bahl 2001). This, however, should not be discouraging because local governments rarely tax properties to their full potential, so there is always room for increasing tax collection.

2.1.2. Intergovernmental transfers: To various degrees, local governments in developing countries depend on intergovernmental transfers. In 1997 transfers represented $42 \%$ of total subnational revenues (Shah 2004). ${ }^{11}$ This dependence arises "because many taxes are not appropriate for subnational governments, because it is difficult to implement the taxes that are appropriate, and because subnational taxes that are appropriate may not yield much revenue” (McLure 2001: 347). As Figure 2 shows, transfers add little to local accountability because citizens only contribute indirectly to this source of financing, thereby the link between taxes paid and services received weakens. In other words, transfers blur the accountability from local governments to citizens because the point of origin and destination of funds does not match, so there is ambiguity about the preferences that these funds should serve.

\footnotetext{
${ }^{11}$ This proportion is for all subnational levels, so it would be higher when only local governments are taken into account.
} 
A high dependence on transfers shifts the focus of local governments' accountability away from citizens and closer to the upper tiers of governments. In other words, this shift changes the direction from local to upward accountability. This happens because, unlike own-source revenues that are controlled by local governments, transfers are controlled by the upper tiers of government. Transfer systems form part of a country's intergovernmental fiscal pact, which is the result of formal and informal political bargains that commonly take place within national legislatures or other intergovernmental bodies (e.g. intergovernmental commissions) dominated by the central government. Local governments turn their attention to these upper bodies because it is in their interest to make the transfer system to their advantage. They are interested in expanding both the total shares of transfers to be distributed and the share of transfers that each local government would receive.

According to the previous logic transfers correlate with low levels of accountability from local governments to citizens, as local governments are more accountable to the upper tiers of government than to citizens. However, this depends on the certainty and predictability with which transfers reach local treasuries, as well as on their size and design. Certainty over funds improves local government's capacity for financial planning. This, in turn, facilitates the engagement of citizens at the local level. In practice, however, local treasuries are seldom certain about the quantum and the schedules of their transfers. One way in which countries have dealt with this is to set the norms of transfer allocation in the national legislation, thereby forcing central governments to deliver transfers according to explicit allocation criteria. However, this only partially solves the problem, because typically the size of the transfer pool depends on the overall performance of the economy (WBI 2003). Thus, even if the transfer allocation formulas and rules are transparent and well known, local governments may not have certainty about the amount they will get.

In terms of size, the previous logic suggests that the higher the proportion of transfers out of total revenues, the weaker the engagement of citizens with local governments. In these cases, local governments' accountability is to the upper tiers of government, so citizens would not be effective in influencing the allocation of transfers. This, however, depends on the design of the transfer; particularly on the level of discretion local governments have to make use of these funds. While conditional transfers have specific spending objectives, and give local governments limited autonomy to meet local preferences, unconditional or block grants give them complete autonomy over the use of these resources (Box 2).

\section{Box 2. Basics of intergovernmental transfer design}

Intergovernmental transfers are used for a variety of purposes, and there are specific transfer designs suitable for each objective. One of the most common objectives of intergovernmental transfers is to close the fiscal gap that arises from the mismatch between revenue means and expenditure needs. In general, there are two broad transfer designs for closing fiscal gaps between revenues and expenditures at the subnational level. National governments may use earmarked or conditional transfers to accomplish specific objectives at the subnational level. Alternatively, national governments may collect revenues on behalf of subnational governments and return them in the form of "revenue-sharing." Commonly, revenue-sharing takes the form of unconditional grants which can be used in any way the recipient wishes.

Central governments often use conditional transfers to advance their own objectives. For some conditional transfers, the central government requires a matching funding from the lower-level governments. These matching requirements may induce a redirection of resources to the areas of spending that central 
governments consider a priority. The cost to this a reduction in the local provision of other locally needed services. For example, in many Latin American countries, decentralization has entailed earmarking substantial parts of intergovernmental transfers to localities for local infrastructure investment. Although not fully effective (since money is fungible, there is usually some substitution of transfers for own-source revenues) the result has usually been the expansion of capital spending, while making the already difficult problem of funding the operation and maintenance of these investments, even more difficult.

Source: Ter-Minassian 1997 and Oates 1999.

2.1.3. Local Borrowing: Currently, the number of developing countries that have efficient markets for local borrowing is still limited. As markets evolve though, borrowing becomes a more viable source of funding, especially for the urban and more developed local governments. Local credit systems are advantageous, because they make available revenue for infrastructure projects and for alleviating the spending responsibility that decentralization places on local governments. However, wide use may interfere with building effective and accountable state-citizen relations. This is mainly because the citizens who receive benefits may not be the same ones who are responsible for paying them back.

In principle, because of intergenerational equity considerations, it makes sense to finance long-lived investment projects with borrowings to spread out the costs of projects among future beneficiaries (Burki et al. 1999). ${ }^{12}$ In order to make sure that local governments use credits for financing capital outlays, subnational credit systems commonly establish a "golden rule" that prohibits using credits to pay current budget deficits. However, because resources are fungible and monitoring of capital projects is often inadequate, it is not always possible to ensure that funds nominally borrowed for capital purposes don't finance other expenditures (Peterson, 2000). Thus, when borrowing is used to cover current account deficits, it has the opposite intergenerational effects, and the costs of services enjoyed by today's tax-payers shifts to future generations.

An additional risk with borrowing is that local governments will finance a variety of projects, exhausting their credit capacity and leaving the political pain of debt service to their successors. For these reasons, the use of credit scores low in building effective local state-citizen relationships. However, citizen participation in the establishment of debt levels and in the use of the credits can be an efficient instrument to reduce risks, and may even contribute to the enhancement of state-citizen interactions. In Nicaragua, for example, local governments can only contract debt to a maximum level of 20 percent from budgeted revenues. When credits go beyond a specific term in office, or over the 20 percent ceiling, local governments must submit their borrowing plans to public consultations (Pineda 2003). In these cases, local borrowing may shift to the left of the continuum of Figure 2, denoting a higher level of local accountability.

2.1.4. Aid: Aid is an additional source of local revenue, but it is not commonly taken into account by studies of fiscal decentralization and local governance. In many cases it amounts to a substantial proportion of local revenues, but since aid is commonly allocated off-budget,

\footnotetext{
${ }^{12}$ In a typical private-sector infrastructure project, only 20 percent or less of investment funds are raised by equity, the rest of the financing comes from credit.
} 
it is difficult to estimate its specific importance. High dependence on aid is associated with medium levels of effective state-citizen engagement for two main reasons.

First, when using aid, governments are likely to be more responsive to donors than to citizens. In general, donors can strongly influence how their money is used so they allocate funds according to their own preferences and perceptions. Second, because aid allocation is often removed from the local legislative process, donors respond to the legislatures back home and not to the aid countries they seek to serve. According to Brautigam (2002: 15) "large amounts of aid can undermine the responsiveness of government to taxpayers, establishing relations of accountability between donors and governments, not between governments and citizens. Only when aid comes as a loan, and citizens understand that it must be repaid through their taxes, are the latter accountability links fostered.” This situation is aggravated by the high number of donor agencies that work without coordination, and whose aid is seldom channeled through local budgets (Box 3). Related to this, Moore (2001: 408) argues that "it has become increasingly difficult for anyone to know what money is being spent on, what by government, or by aid donors in the name of government. There is little accountability of any kind.” The degree to which local government administrators and representatives are empowered in aid assisted development is dependent on the specific terms of the project or intervention being supported. The same is true for citizens' capacity to make effective choices in relation to aid expenditures and actions.

\section{Box 3. Problems in a multi-actor context: The case of Nepal}

Discussions with the staff of the Nawalparasi District Drinking Water Office in Nepal revealed that three donor-assisted projects were operating in the district. All three projects had similar mandates but they had different working modalities. While initiatives supported by the first two donor-assisted projects required contributions from the Village Development Committee (VDC) as well as from beneficiaries, those assisted by the third donor-assisted project required no such contribution from the VDC. Some VDCs that had agreed to work with the first two projects were later found to have switched to the third project in order to save VDC funds. The presence of multiple organizations with similar mandates but different working modalities not only created unhealthy competition in the district but also led to program uncertainty for the first two donor-assisted projects.

Source: The World Bank (2004c).

Despite the fact that aid dependence may lead to low levels of empowerment and weak accountability within countries, donors often influence the governance of the recipient countries, and commonly demand accountability both to them and to their own citizens. They do so by imposing direct and indirect conditionalities on recipient countries. According to Gloppen and Rakner (2002: 38) "with aid increasingly being conditional and with tax reform part of the conditionality agenda, aid and taxation may be positively related." However, conditionality may impede trust and reciprocity between the state and its citizens. In many cases recipient countries focus on meeting conditions of the donors (i.e. reaching specific tax levels) rather than on responding to citizens' preferences. Although conditionality may have negative impacts on state-citizen relations, at this point it is still unclear whether this is actually the case. 
2.1.5. Community contributions: Community contributions are a last source of revenue at the local level. However, because they are often non-monetized and do not flow through the local treasuries, they are not commonly counted as part of the local revenue base. Nevertheless, community contributions are a form of tax through which poor people contribute to the financing of local public goods and services. Besides, in very poor localities the contributions of citizens can sometimes be greater than the official sources of revenue. In principle, it appears that the use of these contributions is associated with high levels of local accountability because contributors are usually the same people that benefit from investments. Due to lack of financial data and information about how community contributions are used, it is not possible to gauge the degree to which community contributions are conducive to enhancing state-citizen relations at the local level. This suggests two areas for future research:

(i) How formal and informal local institutions mediate the relationship between citizen contributions and public works (i.e. how projects are being selected and financed), and

(ii) The role local governments play in the maintenance of these types of public works. Here the issue is that even if communities cover a large proportion of the capital costs (either monetarily or in kind), once the projects are completed, it is not always clear who should be responsible for covering the maintenance costs of these projects.

\subsection{Budget characteristics and local governance}

Unlike revenues, where there is still little evidence and understanding of its role in achieving empowerment of local government and citizens, there is more clarity on how citizens may use a series of expenditure-related mechanisms (i.e. budget expenditure tracking and citizens' report cards) to effectively engage with local governments. Among these mechanisms, participatory budgeting has proved one of the most often used. ${ }^{13}$ Studies have explored a number of factors that influence the performance of participatory budgeting like local political composition (Baiocchi et al. 2005), the degree of participation of different social groups (Houtzager et al. 2003), and the institutional setting in which budgets are formulated and executed (Souza 2001). However, there are other factors associated with the characteristics of local budgets that still require further investigation, such as:

- the size of the local budgets

- the composition and flexibility of the budgets

- the overall level of transparency of the local systems of public finance.

2.2.1. Budget Size: The overall size of the budget helps explain the engagement of citizens in local governance as well as the extent to which local governments allocate expenditures in accordance to citizen's preferences. ${ }^{14}$ Having adequate budgets is a fundamental

\footnotetext{
${ }^{13}$ See footnote 3.

${ }^{14}$ When analyzing the association between budget size and citizens' participation, it is often difficult to ascertain the real size of budgets. This is because (i) budgets are composed of several revenue sources that are
} 
condition of decentralization, because in order for local governments to be responsive, they require sufficient resources and autonomy. Without this, engagement may lead to citizens' frustration and disappointment (WBI 2003 and Heymans and Mussa 2004). From a rational perspective, this is self-evident. If there are no resources to distribute, people will be unwilling to bear the cost of engagement.

According to this rationale, budget size is positively associated with the level of citizens' empowerment. Several studies have already found evidence of this association, but they have not yet found the threshold at which budget size becomes associated with citizen empowerment. Souza (2001), for example, found that an increase in local revenues was one of the main reasons why two Brazilian cities adopted participatory budgeting. The cities of Porto Alegre and Belo Horizonte started participatory budgeting during the 1990s and experienced the two highest average annual rates of increase in per capita total revenue from 1989 to 1994 (Box 4). Some similar, but contrasting, cases are those of Ethiopia, India, Mongolia and Mexico, where lack of resources is associated with low levels of empowerment. A number of World Bank studies (WB 2001 and Heymans and Mussa 2004), found that local budgets in Ethiopia are too small to stimulate citizen participation. Similarly, another World Bank study in India (2004a) found that the goals of better accountability and citizen engagement are unmet because local budgets are too small to attract the attention of the local population. A report on fiscal decentralization in Mongolia (Center of Mongol Management 2005) also found that the fact that soum economies are weak and their revenues limited has a preventive impact on encouraging participation. Finally, Fox and Aranda (1996) found that in the State of Oaxaca in Mexico the very small budgets of rural and indigenous communities prevented them from participating and making community contributions.

\section{Box 4. Budget size and local participation: Participatory Budget in two Brazilian cities}

Between the 1970s and the 1980s all Brazilian cities, especially large ones, were in financial disarray. The 1988 Constitution introduced a series of reforms which allowed many municipalities to improve their financial situation, particularly of state capitals. These reforms and the increase in local revenues had a direct impact on the widespread adoption of participatory budgeting (PB) in Brazilian cities.

Participatory budgeting began in Porto Alegre (PA) in 1989 and in Belo Horizonte (BH) in 1993. Jayme Jr. and Marquetti (1998) show that -between 1989 and 1994- PA rose from $10^{\text {th }}$ in the ranking of state capitals' per capita total revenue to 5 th. More strikingly, $\mathrm{BH}$ jumped from $22^{\text {nd }}$ to $4^{\text {th }}$ over the same period. According to the authors, the average annual rate of increase in per capita total revenue between 1989 and 1994 reached 24.45\%; in BH, (the first in the ranking) and 13.54\% in PA, (the second in the ranking).

BH's performance shows that local taxpayers in several state capitals were under-taxed. It also shows that many popularly elected mayors, as opposed to appointed mayors who had governed state capitals during the military regime, opted to raise taxes in order to fulfill their commitments to their electorate. However, PA and BH have better economic and social indicators than the average Brazilian city. This has allowed

often unpredictable, and (ii) there are substantive differences between budgets that are planned, authorized, and executed. In particular, there are often substantive gaps between the authorized and the executed budgets. This results either from unrealistic revenue forecasts or because expenditure demands are so high that local governments are forced to authorize budgets that they know in advance that they will not be able to meet. For example, a study on Kenya found that treasuries effectively operate a shadow budget to track the actual available budget, because forecasted revenues are unrealistic and cannot be collected (DFID 2002). 
their local governments much more room for increasing local taxes and, consequently, to have more revenue to set aside for distribution through participatory budgeting schemes.

Source: Extracts from Souza (2001).

Despite the association between budget size and citizens' empowerment, budgets in developing countries are never adequate to provide basic services for marginalized populations. For this reason, such association must be seen in light of the power that citizens have to allocate not total budgets, but their relative increases. Other considerations include seeing the appropriateness of the budget size -both capital and recurrent- relative to short, medium and long term expenditure needs. Citizens may have power to influence budgetary allocations at a specific point in time, but that may create future budgetary commitments that would affect their power to influence future budgetary allocations. This is especially problematic when large capital budgets are allocated with short-term perspectives, disregarding the future recurrent expenditures that such investments would generate. Also, in contexts of high budget constraints, heavy capital investments in one year may preclude other short and long term capital investments. As a result the power of future generations to influence budget allocations may decline. One way to deal with this, which has began to operate in many developing countries -yet imperfectly- is by passing multi-year budgets that push for the alignment of budget costs and benefits in longer -than annual-periods of time.

2.2.2. Budget flexibility: In addition to size, the flexibility, or portion of the budget over which citizens have power, also determines the capacity of local governments to meet local preferences. If budgets are too rigid, or the portion that citizens can influence is too narrow, then citizens' are unlikely to choose to engage, because the chances of affecting outcomes will be slim (Gaventa and Valderrama 1999). "Flexibility" refers to two factors in local budgeting:

(i) the level of local governments' control over non own-source revenues, and

(ii) the relationship between capital and current expenditures.

Regarding the first, local control is often constrained by the conditional aid, block grants, and borrowing that reaches local treasuries with specific conditions and predetermined objectives. A high proportion of these revenue sources reduce flexibility for spending according to local preferences, which in turn affects the level of citizen engagement in spending decisions. Concerning the relative amount of capital to current expenditures, citizens -and sometimes local governments- have little capacity to influence this relationship.

Local budgets in developing countries typically have a large component of current spending (mainly wages), which is difficult to reduce in order to increase the capital budget. In Mongolia, for example, research found that the budgets of local governments mostly cover current spending only (mainly wages and goods and services, see Table 1) without reflecting the priorities of capital expenditures (Center of Mongol Management 2005). 
Table 1. Total Budget Expenditure in Soums and Aimags (percent)

\begin{tabular}{|l|r|r|r|r|}
\hline \multicolumn{1}{|c|}{ Types of expenditure } & \multicolumn{1}{c|}{$\begin{array}{c}\text { Khishing- } \\
\text { Undur }\end{array}$} & Baruuturuun & \multicolumn{1}{c|}{$\begin{array}{c}\text { Average } \\
\text { Soums* }\end{array}$} & \multicolumn{1}{c|}{$\begin{array}{c}\text { Average } \\
\text { Aimag** }\end{array}$} \\
\hline CURRENT EXPENDITURE & $\mathbf{1 0 0 . 0}$ & $\mathbf{1 0 0 . 0}$ & $\mathbf{1 0 0 . 0}$ & $\mathbf{9 5 . 6}$ \\
\hline 1. Goods and services & $\mathbf{1 0 0 . 0}$ & $\mathbf{1 0 0 . 0}$ & $\mathbf{1 0 0 . 0}$ & $\mathbf{9 3 . 7}$ \\
\hline a. Wages and salaries & 40.8 & 53.8 & 47.3 & 41.4 \\
\hline b. Social security contributions & 9.7 & 14.3 & 12.0 & 10.3 \\
\hline c. Purchase of goods and service & 49.5 & 31.8 & 40.7 & 41.9 \\
\hline 2. Subsidies and transfers & $\mathbf{0}$ & $\mathbf{0}$ & $\mathbf{0}$ & $\mathbf{2 . 0}$ \\
\hline CAPITAL EXPENDITURE & $\mathbf{0}$ & $\mathbf{0}$ & $\mathbf{0}$ & $\mathbf{4 . 4}$ \\
\hline TOTAL EXPENDITURE & $\mathbf{1 0 0 . 0}$ & $\mathbf{1 0 0 . 0}$ & $\mathbf{1 0 0 . 0}$ & $\mathbf{1 0 0 . 0}$ \\
\hline
\end{tabular}

Source: Own, based on CMM (2005). *Soums are the lowest formal tier of government. Soum data is for 2003. ** Aimags are intermediate-level governments. Aimag data corresponds to the 2002-2004 average for the aimgs of Bulgan, Uvs, Khentii, Dundgobi

With high levels of current spending, the power of citizens to influence local budget allocations depends largely on the size of the capital budget -and just marginally on those non-wage parts of current expenditures over which citizens could have some kind of power. In the participatory budgeting process in Brazil, for example, citizens' voice over budget allocations is restricted to the decisions on infrastructure investment. According to this rationale, a high proportion of capital spending should be positively associated with the level of local participation. Although this association still needs to be tested, there is already evidence in its favor. Souza (2001) found that when municipalities do not have to devote large portions of their budgets to cover basic education expenditures, they free up resources to introduce innovative policies like participatory budgeting. Similarly, another quantitative study found a positive and significant relationship between high proportions of capital expenditure in municipalities' total expenditure and the likelihood that participatory budgeting is implemented (Baiocchi et al. 2005). However, the causality of the association between budget size and availability of participatory mechanism and processes remains to be empirically tested. It is not yet clear if such mechanisms and process exist because budgets are large, or if the fact that budgets are large call for the creation of such mechanisms.

2.2.3. Budget transparency: The overall level of transparency in which local budgets are formulated, executed, and evaluated is another factor related to the empowering effect of participatory budgeting. ${ }^{15}$ Transparency is crucial because even if budgets are large and flexible, unless they are decided, allocated, and monitored in a transparent fashion, citizens will not have the information to make effective choices. Availability of information is actually a crucial determinant of both accountability and citizens' participation. For example, a WBI (2003) study found that in Latin America access to information on the origin and the object of local resources, increases citizens' trust, which is a basis of civic

\footnotetext{
${ }^{15}$ Transparency has been extensively recognized as a central piece of good governance in budgetary practices. A wide range of international (IMF, WB, UN) and non-governmental organizations have been supportive of transparency for the last few years. There are several important initiatives for budget transparency that have been carried out in many parts of the world. For a brief review of these efforts see Norton and Elson (2002).
} 
participation. Similarly, research on community-level user groups in India found that the most common reason for nonattendance in community meetings was lack of information (Alsop et al. 2002). Also, when information is available and budgets are transparent, citizens counterbalance the power of local governments by monitoring their performance and ensuring that they commit to their spending priorities.

In addition, transparency may also have an indirect effect on people's capacity to make effective choice by increasing their willingness to pay taxes. When people see that governments spend budgets in a transparent and responsible way, they are more inclined to pay taxes voluntarily (Box 1). Thus, a virtuous cycle emerges. Budgets increase, and presumably more people participate in the allocation of larger shares of spending. Therefore transparency is an important component of local state-citizen relations because unless citizens perceive that their fiscal system is reasonably transparent, efficient and trustworthy, they are unlikely to attempt to influence the allocation and oversight of resources. Research in India, for example, found that it is precisely because of lack of transparency and high levels of corruption that people do not engage in those local fora where budgets, finances, and development plans are discussed (Alsop et al. 2001).

\subsection{Costs of participation and local governance}

In addition to the source of local revenues and composition of local budgets, the costs to citizens of engaging in local governance are another determinant of empowerment. Studies on participation explore a number of factors that hinder or stimulate citizens' engagement in public affairs: collective action problems, organizational capacity of different groups, risks of elite capture, etc. However, the costs of participation have received little attention. No studies have formally incorporated the costs of participation into the analyses of mechanisms such as participatory budgeting or participatory public expenditure management (WB 2003).

Beyond the normative assumption in decentralization theory that people have a natural desire to participate at the local level, it is evident that citizen engagement has associated costs. High costs may incite citizens to rely on elected representatives, or avoid participating altogether. An accurate assessment of how costs act as determinants of citizen engagement requires an analysis of both the costs of the different stakeholders, and their relationship to expected benefits.

According to a rational model, individuals or groups participate only when the benefits from doing so are larger than the costs incurred. However, identifying and measuring the costs and benefits of participation is challenging. Normative studies on decentralization assume that the benefits of participation surpass the costs, but as Mansuri and Rao (2004:11) argue, this is not necessarily so:

The exercise of voice and choice can be costly under certain conditions. At the most basic level, it may involve real or imputed financial losses due to the time commitments required for adequate participation. In addition, participation may lead to psychological and physical duress for the most 
socially and economically disadvantaged, since genuine participation may require taking positions that are contrary to the interest of powerful groups. While the premise of participatory approaches is that the potential benefits outweigh such costs, this is by no means certain.

Some costs are easily quantifiable and some are not. Easily quantifiable costs can be indirectly measured as the opportunity costs of labor and transportation costs. ${ }^{16}$ Not all individuals or groups in society face the same costs of participation. In principle, one would expect better-off individuals to participate less than poor ones, as they have a higher opportunity costs to labor. However, paradoxically, the poor and very poor often face very high costs of participation. This is so because even if the opportunity cost to labor of these groups is low, their necessity of subsistence makes their time more valuable. Another factor that is often recognized as directly raising the costs of participation is distance. Poor people often live far away from the centers of decision-making, so transport costs are high. Studies find that distance prevents poor people from participating, even when they have the legal right and the mechanisms to do so. In Ethiopia, for example, community members can approach local councils directly, but they do so very infrequently because of problems of physical distance and poor transportation (Govender 2003).

Poor and marginalized individuals and groups also face a number of other not easily quantifiable costs that have a negative impact on their capacity to make effective choices. Ex-ante, poor people face high costs for accessing information. By not having information, poor people in remote areas are not aware of the options they have to make meaningful choices. Getting that information, when available, increase their costs of participation. However, even if information were to have no cost, effective participation would not be assured, as citizens also face other social costs. Where community values and norms are not conducive to fair and democratic practices, poor and marginalized groups often bear the expost costs of deviating from social norms. At the extreme, mechanisms for citizens' participation may be in place and formal rules may ensure that marginalized individuals have the right to participate in public decisions, but the costs can be immense, such as physical violence and ostracisms. For example, research on women's rights has documented these costs, illustrating the physical violence that women and face when they choose to participate in the political sphere (Kabeer 1999).

All the previously described costs are borne by individuals or groups that choose to participate, but often costs accrue also to local governments that are formally in charge of participatory processes. A study on citizen participation and local accountability in Kenya concluded that "participation is costly, both for the local governments and for citizens" (DFID 2002). The organization of town-hall planning/budgeting meetings and conducting quality surveys represent direct monetary costs for local treasuries. Also, sometimes, local governments must incur the cost of visiting communities. A study on Ethiopia, for example, found that travel from the woreda capital to communities was often hindered by shortage of government budget for per diem and fuel (WB 2001).

\footnotetext{
${ }^{16}$ This is a combination of the time that it takes for an individual to participate with the distance that he or she needs to travel to make a choice.
} 
In order to fully understand the impact that costs have on the capacity of people to make effective choices, costs must be compared to expected benefits. Costs may be high, but the associated benefits may also be high. Thus, in a rational world, citizens may choose to participate as long as the associated net benefits are positive. This helps explain why poor people don't participate; as they often expect or experience few benefits from doing so. This was the case of community participation in the State of Oaxaca in Mexico where rural indigenous communities stopped participating and making contributions when they realized that their efforts received so little budget support that the impact of their engagement was often negligible (Fox and Aranda 1996).

Despite the robustness of this rational model, there are two problems associated with it. First, it does not explain cases in which the individual costs of participation are notably higher than the associated benefits. For example, in elections, costs are individually born, but benefits are collectively distributed. In such a typical case of a collective action problem, individuals can enjoy benefits without having to pay the costs of engaging in a collective decision-making process.

The second and more complicated problem of the rational model is the conceptualization and measurement of benefits. In principle, there are two types of benefits associated with participation: direct and indirect. Direct benefits are the ones that individuals derive from choosing to engage in local governance. The problem with individual benefits is that they are both hard to quantify and almost always uncertain. Ex-ante, individuals only have an expectation of the distribution of benefits, so any attempt to quantify them must calculate the total individual benefits, as well as weigh them against the expected probability that benefits will be delivered. ${ }^{17}$ Indirect benefits of participation are even more difficult to conceptualize and measure; they are the intrinsic value that individuals derive from participation. Their measurement involves methodological complexities, because instead of manifesting in concrete -and somehow measurable- outputs, they manifest in intangible ways, such as the building of "citizenry" or "sense of belonging." As discussed in Section 4, an individual or group may choose to participate in political life solely to exercise their rights or to broaden their sense of social belonging. Thus, even if these benefits cannot be easily measured, they have intrinsic value and as such form part of the individual's welfare.

\section{Impacts of decentralization on the distribution of power at the local level}

The analysis on the fiscal determinants of empowerment has thus far largely conceived local governments as a single unit of analysis, without recognizing horizontal and vertical distributions of power at the local level. Horizontally, local power is distributed between elected representatives and administrative officials, and vertically among local governments, citizens, and upper tiers of government. The distribution of power also determines the extent to which fiscal variables have an impact on the capacity of citizens and local governments to make effective choices.

\footnotetext{
${ }^{17}$ At times there is ex-ante certainty about the distribution of benefits. For example, a number of micro-finance projects, ask people to participate as a pre-requisite to be eligible for credits. In these cases, individuals know the benefit of their participation in advance, and can discount them from their costs.
} 
3.1. Horizontally: The relationship between local bureaucrats and politicians is highly contextual, but in general, literature suggests that there is tension between these two groups in regards to local revenue generation and public spending. Such tension arises from an unequal distribution of power among them and from what Fjeldstad (2002) calls a "trust deficit" in political-administrative relations. According to a World Bank research project on local organizations in India and Nepal (WB 2004b and WB 2004c) conflict often arises because of poorly defined allocations of functions between administrators and local politicians. Additionally, there are considerable differences in the levels of assets and power in these two forms of local body. In Nepal for example, one local officer commented that "it is wrong to shift responsibility of implementing agricultural programs to District Development Committees, as they currently lack adequate human, finance, and physical assets." To cope with these problems, the studies suggests the establishment of a clear set of rules for the allocation of local responsibilities, a balanced distribution of resources, and a realistic assessment of the capacities of administrators and local elected politicians to perform their mandated responsibilities. ${ }^{18}$

Concerning fiscal issues, one can argue that while administrators prefer generating enough tax revenue to cover their wage bill, politicians are less inclined to raise taxes. This is both because administrators do not have much control over the other sources of local revenue (i.e. grants, credit and aid) for covering their wages, and because politicians are interested in reelection, and raising taxes may reduce their popularity. What this suggests is that there is more likely to be coercive tax enforcement when the balance of power is in favor of the local administration, rather than of the elected officials (Fjeldstat 2002). Although the relationship between elected politicians and local administrators still requires further elucidation, a study by Schneider (2003) found that the differences in the distribution of power among these two groups affect the levels of tax collection in the local sphere. Particularly, this study found that while political decentralization is negatively and significantly associated with tax capacity (measured as taxation as a percentage of GDP), administrative decentralization does not have a significant effect on tax capacity.

Assuming that the degree of political and administrative decentralization is a good approximate of the horizontal distribution of power, Schneider's study (2003) proves empirically that tax collection goes down when power gravitates around local elected politicians. ${ }^{19}$ This shows that the level of tax collection is influenced by the institutional arrangement between local elected representatives and administrators, over which citizens have little control. Because local administrators and elected officials have different objectives and spending priorities, some measures to keep them accountable to each other and to citizens must be established. This is challenging because in situations where governments are in transition to greater levels of decentralization local governments do not always receive full control over their newly transferred responsibilities. To various degrees, central governments continue to influence the local level, through line department officials. As a result, local bureaucrats are not subject to the control of citizens or elected

\footnotetext{
${ }^{18}$ One particular lesson derived from this study, is that line agencies are often better equipped with technical skills than elected bodies. Thus, the allocation of local functions should take this into account.

${ }^{19}$ However, the study does not provide evidence that tax collection goes up when local power is tilted in favor of local administrators.
} 
representatives, as they continue to respond to the objectives of higher line departments. In Mongolia, for example, line departments, rather than local officials, are in charge of budget planning, allocations, and accounting (WB 2004d). Similarly, in Nepal the Village and District Development Committees (elected bodies) formulate their development programs based on the instructions received from the line departments, and they do nothing more than rubber stamp them (WB 2004c). Local elected officials do not have any decision making power over these activities and, even if they are nominally responsible for the budgets, they are not fully accountable to the citizenry. ${ }^{20}$

3.2. Vertically: The inability of local governments to be fully accountable to the citizenry for the allocation of resources uncovers a broader challenge of fiscal decentralization. Can local governments design policies and deliver services, according to local preferences, without sufficient financial resources and flexibility to meet local needs? As noted above, local budgets include large portions of transfers that often reflect the spending priorities of the upper tiers of government. Local governments therefore often merely disburse resources decided by other units of government, and at times are even sidelined from the design and implementation of projects that are completely controlled by the upper tiers of government, or outside donors (see Annex 1). However, transfers play a crucial role in local public finances, not only because the resources they bring to local governments are in many cases their only source of financial subsistence, but also because they serve to advance national spending priorities at the local level (i.e. fiscal equalization -provision of services at similar tax rates). The challenge is then to align local preferences with national priorities in a context of decentralized governance.

Literature on fiscal decentralization deals with this challenge by arguing for the recognition of the importance of intergovernmental dimensions of local public finances (Litvack et al. 1998). There are two main ways in which this is done:

(i) crafting a clear assignment of revenue and expenditure responsibilities among different tiers of government, and

(ii) creating collegiate bodies where all tiers of government have a say in the allocation of resources.

The first option requires assessment of the real capacities of local governments to perform the functions mandated to them. It is also necessary to redefine the role that national governments play in a context of decentralized governance. Although sometimes misunderstood, decentralization does not imply "less” central presence, but rather a “different” one. According to Bird (2000: 41), "Decentralization of a function does not mean that the central government no longer has any responsibility in the area. What it means is that the nature of central responsibility is changed from direct service delivery to regulating and monitoring the efficiency and equity of services delivered by local governments.” In addition to the monitoring and regulating function of central governments, higher tiers of

\footnotetext{
${ }^{20}$ In Mongolia, line departments occasionally give local governments discretionary budgets for their local needs. In these cases, however, the amounts allocated are usually quite small.
} 
government can also be involved in training and capacity building of local governments, as well as auditing and evaluating their fiscal performance (Shah, 1994).

The creation of intergovernmental bodies is the other mechanism to align national priorities with local needs. Although the design of such bodies can be quite diverse (Box 5), the general purpose is to create semi-autonomous bodies or forums where various intergovernmental but also other- actors can interact with each other in a nonconfrontational setting. These intergovernmental institutions regulate systems of transfers, and may also serve as a forum to discuss local government's own-source revenues and borrowings. Such an entity would allow central governments to advance national development strategies, while giving local governments the opportunity to express their needs. To a large extent, the success of such institutions may depend on their specific design and on the political will of the national government to share power with subnational units.

\section{Box 5. Institutional design for intergovernmental fiscal relations}

There are five main alternatives of intergovernmental fiscal arrangements, especially for the design of the grant systems:

- The first is for the federal government alone to decide on it. This alternative negates federalism and would not be acceptable in many countries

- The second is to set up a quasi-independent body, such as a grants commission, to design and reform the system, as practiced in Australia, India and the Republic of South Africa (this alternative is prone to more ideal solutions rather than pragmatic approaches and therefore runs the risk of presenting complex solutions and recommendations that may not be politically palatable)

- The third alternative is to use federal-state committees negotiate the terms of the system as is done in Canada

- The fourth alternative is to have a joint intergovernmental cum inter-legislative commission such as the Finance Commission in Pakistan

- The fifth alternative is to have an intergovernmental legislative body, such as the upper house of the German Parliament (Bundesrat) as in Germany.

The structure of intergovernmental fiscal relations should be specific to the context of each country, depending on constitutional restrictions, political realities and other contextual factors.

Source: Shah 1998 and Bird 2000.

\section{Empowerment: means and ends}

So far, the paper has argued that empowerment is most likely to be present when three conditions prevail: low costs to participation; large and flexible budgets; and a high proportion of tax revenues from a local base. These determinants of empowerment, however, do not necessarily produce outcomes that are progressive and pro-poor. Normative approaches to decentralization have largely assumed that a high degree of engagement by citizens -and local government- in decisions on local governance results in effective outcomes, but there is not yet sufficient empirical evidence to support this position. Of those few recent studies that have started to look at the outcomes of citizen participation and especially at its impact on the poor, the general conclusion is that "whether local 
participation in governance systems of public goods and services will really have a positive impact on low income groups is unclear" (Von Braun and Grote 2000). ${ }^{21}$

There are two rationales that have been used to justify an interest on empowerment: an intrinsic and an instrumental one. The first rationale envisions empowerment as an end in itself. According to this vision citizens will develop the capacity to choose whether or not to be part of political processes, which is itself a desired outcome. For example, a study on participatory budgeting in Brazil found that participation is valued more for providing "citizenry" to formerly excluded groups of society rather than for the material gains it may bring (Souza 2001). This intrinsic belief in the value of empowerment is often also linked to instrumentalist arguments. Once previously disadvantaged groups are empowered to engage in local level decision making, they might be able to get expenditure and service delivery decisions in their favor.

According to the second approach, empowerment is a means to achieving concrete pro-poor outcomes in a decentralized context. So far, this instrumental relationship has not been proven, but studies have begun to distinguish the conditions under which such a link can take place. According to the OECD, decentralization is an effective way to reduce poverty in countries with functioning states, but not in countries where the state lacks the capacity to fulfill its basic functions (Jutting et al. 2004). Similarly, Von Braun and Grote (2000) argue that the capacity of decentralization to reduce poverty depends on the type of decentralization adopted. These authors found that while "political decentralization" often benefits the poor, by involving civil society in policy processes, "administrative" and "fiscal" decentralization does not have any impact on poverty reduction. Rao et al. (1998) argue that decentralization could reduce poverty, but their analysis specifically centers on the redistributive capacity of the transfer system, which is usually centrally managed without intervention from local governments.

In order to test the instrumental relationship between empowerment and poverty reduction, research needs to move away from the current normative stance of the overall benefits of general citizen participation. Clearly, this relationship needs to be further qualified as different groups and individuals derive different benefits from diverse budget allocations. Thus, it is of primary concern to analyze the budgetary allocation among different items and to gauge the incidence that each of these allocations has on the poor. For a number of reasons, this is not easily done. As Tanzi recently argued (2004) the notion of efficiency in public expenditure refers to the financial costs associated in pursuit of a specific goal. However, that goal could be inefficient in a public or social welfare sense. This he calls "efficiency with the wrong goals" and draws attention to the fact that a socially right allocation of spending ("right goals" -like education and health) can either be efficiently (low cost) or inefficiently (high costs) attained. Once the budget allocation is done according to the "right goals" there are two additional considerations to bear in mind.

(i) even if there is a high proportion of spending on the "right goals," which are often seen as favorable for the poor, they may not always help the poor. A thorough

\footnotetext{
${ }^{21}$ See for example Rao et al. (1998), Von Braun and Grote (2000), Souza (2001), Jutting et al. (2004), and Schneider (2003).
} 
understanding of this relationship calls for looking at both the quantitative allocations of the budget (by sector, item, or project) and at the qualitative outputs that those allocations generate. For example, a large portion of the budget could go to education, but if most of those resources go to increase the benefits of the teacher unions, that spending allocation may not have direct benefits for the poor $^{22}$, and

(ii) supposing that local governments have rightly identified the type of spending that benefits the poor, the remaining challenge is to ensure that the expenditures actually reach the intended beneficiaries. Literature on decentralization examining this implementation problem has found that local actors do not have equal capacities and opportunities. More powerful groups are in a better position to shift public spending and public decisions altogether- to their favor, a situation commonly referred to as "elite or local capture.” According to research, if communities or the state cannot influence or control the actions and power of local leadership, this often leads to investments which benefit elite interests and an under-investment in public good and services for the poor (Von Braun 2000). ${ }^{23}$ In China, for example, the existence of a powerful elite is associated with the high increase in the Gini coefficient from 1980 t0 1995. Similarly, according to Von Braun (2000: 15) in India "the elite, particularly those from higher castes, are mostly seen as those who divert government resources for their own use. In some areas, local leader are seen as selfish and corrupt and area cited as one of the reasons for lack of development in the area."

Thus, both because of lack of consideration of the qualitative outputs of budgets and because of elite capture problems, empowerment may not instrumentally serve the poor. However, in cases where large numbers of people (e.g. woman, ethnic minorities) are excluded from the public decision that affect their life, empowerment may be a valued outcome in its own right. Besides, the analytic division between the intrinsic and the instrumental approaches to empowerment is not definitive. In fact, both approaches to empowerment appear to be closely associated. Intrinsically disempowered individuals or groups are also likely to be instrumentally disempowered. Similarly, intrinsically empowered individuals or groups are also likely to be instrumentally empowered.

\section{Conclusion: practical implications and further research}

The focus of this paper has been largely theoretical, but there are practical implications related to the fiscal determinants of empowerment. The paper suggests a number of ways in

\footnotetext{
${ }^{22}$ Thus far, studies of participatory budgeting have not addressed this issue (perhaps for lack of disaggregated data at the subnational level), but without such analysis, it will be difficult to find out if the use of this mechanism benefits the poor. In Porto Alegre and Belo Horizonte in Brazil this problem is partially managed by using a system in which each region's share of total investment is weighted by its level of poverty and infrastructure needs. This guarantees a progressive distribution of resources (Souza 2001).

${ }^{23}$ From a rational cost-benefit point of view this happens not only because the poor do not have an incentive to engage with government (as they bear all the costs but share the benefits equally), but also because those who participate (those who have positive net benefits of doing so) have interests sufficiently different from the (poor) majority.
} 
which changing the conditions of local public finances can empower citizens and local governments. The general policy prescription would be to strengthen local public finances, primarily by increasing the local governments' own-source revenues and capital budgets, and by lowering the citizen's costs of participation. The validity of this prescription however, hinge upon a number of considerations that deserve further examination and empirical evidence.

(1) Revenues: The single most important policy recommendation to enhance the capacity of citizens to make effective choices is to increase local government's own-source revenues. However, there is a number of considerations associated with this. First, local governments in developing countries are often incapable or unwilling to make a substantive increase in their own-source revenues. The reasons for this range from low institutional capacities and high political costs to weak tax bases (Box 6), and need addressing if local revenues are to be used as a means of enhancing empowerment.

\section{Box 6. Problems with local revenues in India}

The States of Kerala and Karnataka in India gave Gram Panchayats independent revenue raising powers, but this power has not been effectively used in either state. Thus, in both states, own-source revenues are negligible -less than one percent of Gross State Domestic Product. A number of reasons have been suggested for this weak revenue performance:

- an unwillingness by local officials to enforce tax laws

- the limited capacity of local government officials to effectively administer a revenue system

- weak administration procedures, i.e., tax rolls are not maintained, assessments are not done in a scientific way nor updated, collection procedures are not efficient

- the property tax base is not defined in a way that promotes increases in property values for purposes of taxation

- there is a need for more productive bases to tax

- taxpayers see little benefit from paying taxes to local governments

- local officials have little incentives to raise additional taxes; they face little reward if they do and little penalty if they do not (relatively few Gram Panchayats have opted to levy the highest property tax rate allowed)

Source: The World Bank 2004a.

Second, although public finance theorists have made a very strong argument that local government's increases in own-source revenue enhance local accountability, it is still uncertain what the quantum of such increase should be. Theory seems to suggest a linear relationship between own-source revenues and accountability, so the higher the proportion of own-source revenue, the higher the level/strength of local accountability. However, this may not be the case because there is a limit on how much local governments are willing to raise in revenue and how much citizens are willing to pay for public services. Analyses need to explore how much citizens - of different income levels and in different country contexts are willing to pay for different levels of coverage and quality of services, and what political costs local governments are willing to bear for increasing revenues. An optimal level of own-source revenues could be set according to these two factors and anything above or below that level would reflect a sub-optimal relationship between citizens and government. 
Thus, if increases in own-source revenues are to be feasible and sustainable, they should go beyond the political costs of taxation and increase the coverage and quality of services.

Third, due to the limitations in the systems of local taxation, increases in local revenues are likely to come from intergovernmental transfers. This calls for a careful design of the intergovernmental transfers. In general, a balance between autonomy at the local level (mostly through unconditional transfers) and control, evaluation, and oversight from the upper tiers of government should be reached. In other words, local governments need sufficient resources to respond to citizens' preferences, but at the same time the upper tiers of government require auditing, monitoring, and sanctioning powers to hold local governments accountable over the use of such resources.

This consideration calls for articulating the local fiscal systems with the intergovernmental fiscal structures. This articulation is often absent and that adversely affects local public finances in contexts of decentralized governance. Two concrete consequences of this lack of articulation are low levels of local tax effort and crowding out of local tax rates. Concerning tax effort, although there is still debate about the impact that intergovernmental transfers have on the behavior of local governments to collect taxes, there is empirical evidence that an extensive use of transfers may discourage local tax effort because local governments face lower incentives to search for new sources of revenue or to more efficiently collect existing taxes (Bahl and Linn 1992). For this reason, the design of transfers should be such that they do not undermine incentives for local revenue generation. This can be done either by delivering transfers to local governments after they have raised their own revenues, or by including fiscal effort components in the transfer allocation formulas. In terms of crowding out local tax rates, the problem is that even if central governments allow local governments to set their tax rates, they seldom reduce their own tax rates in order to create tax space for local governments. In the case of local piggybacking in central taxes, local rates must take over a portion of the central rate and may not be applied on top of it. Unless this is done, local government's autonomy to set tax rates would be de facto limited.

Fourth, the hypothesis that the origin of the source of revenues has an effect on the capacity of individuals and local governments to make effective choices still needs empirical validation. This paper argues that the origin of the revenue source matters, but other studies argue against. Hansohm et al. (2002), for example, argue that in Namibia there is a substantial level of accountability from the state to citizens, even though local governments derive a very small proportion of their income from own-source revenues. This alternative hypothesis suggests that what determines accountability is the "flexibility" or "discretion" with which local governments allocate resources rather than the "source" from where the revenue originates. Other studies go even further and argue that "what matters for local citizens is whether the resources, wherever they come from, are properly used to provide services" (Devas 2002: 11, emphasis added). One problem in focusing on service provision alone is that this view only examines the instrumental effect of empowerment, ignoring the fact that empowerment also has an intrinsic value, which even if it cannot be directly observed -as a change in the coverage or quality of service provision- enhances the development of citizens' assets and capabilities to make effective choices. 
(2) Expenditures: Concerning local expenditures, the policy recommendation would be to increase the size and flexibility of the budget over which citizens have power. There are, however, at least two considerations associated with this recommendation. First, local government's capacity to increase its budget flexibility is limited by the lack of full control over the allocation of certain expenditures -like wages- that are decided by line departments. This situation calls for consolidation of power in local elected bodies, but this involves a series of deep civil service and administrative reforms that are seldom jointly included in the decentralization process. Moreover, research shows that bureaucrats resist giving up power to local politicians. Overall, literature suggests that local elected governments should have the power to hire and fire local-level employees. This would help eliminate the conflict of local government employees' dual responsibility between accountability to the unit of government to which they formally belong and to the level of government in which they work. Unless local governments have power and discretion to control their budgets, it is difficult to imagine that they will be in a position to cope with the spending preferences of their citizens, and therefore their capacity to make effective choices will be limited.

Second, the association between budget size and flexibility with empowerment will only hold if the right mechanisms for state-citizen interaction are in place. Local budgets could be large, but unless citizens have a way to transmit their spending preferences to local governments and to hold them accountable for their actions, their empowerment will be limited. This means that the specific design of mechanisms for state-citizen interaction has a direct influence on the effectiveness of such interaction. In practice, there is a variety of designs: citizens may discuss and influence the allocation of total budgets (like in Kolomyia, Ukraine) or just of capital budgets (like in Brazil). Citizens may choose from a menu of spending priorities, or they may come up with their own spending priorities. In Porto Alegre, for example, citizens have the power to make choices from a menu of priorities and receive funding or they may go outside that menu and receive less funding. This is important because it determines who participates in the allocation of budgets and who ends up benefiting from those allocations. Desposato (in Souza 2001), for example, found that the top priority of the poorest citizens in Brazil is economic survival and not infrastructure, which is the main focus of participatory budgeting in that country.

Finally, as in the case of revenues, the notion that size and flexibility of budgets are determinants of citizens' empowerment still needs empirical validation through large-scale surveys. One exception is recent quantitative research on participatory budgeting in 5,400 Brazilian municipalities (Baiocchi et al. 2004). According to this research there is a positive and significant relationship between high proportions of capital expenditure in a municipality's total expenditure and the likelihood that participatory budgeting is implemented. However, such type of research should be conducted in other countries and contexts; it could begin in countries like Bolivia, Guatemala, Nicaragua or Peru that have sufficient experiences with participatory budgeting.

(3) Costs of participation: Reducing the costs of participation is a last recommendation to increase citizen empowerment. However, there is still a lack of empirical evidence on the effects of the costs of participation. In order to gauge the real impact of such costs, a first 
step would be to create a methodology to measure them. Costs are diverse, context specific, and not always easily identified and quantified. For example, in addition to the costs discussed in this paper, in certain contexts the costs of administering a local tax system can be so high that they adversely affect the degree of empowerment. Having a system of local taxation may be conducive to the establishment of effective and accountable state-citizen relations, but it may not be cost-effective. At the extreme, the costs of raising local revenues in poor countries (with weak tax bases, sparse populations, etc.) could out-weigh the expected tax receipts. ${ }^{24}$ In such cases, a centralized system of local taxation may be more effective.

In addition to costs, the benefits associated with participation should be identified and measured. Such exercise must acknowledge the differences between intrinsic and instrumental benefits. Primary data collection is required for these measurements and also for rigorously testing how the costs and benefits of participation affect citizens' and local governments' capacity to make effective choices. This is where this paper stops and empirical work must begin.

\footnotetext{
${ }^{24}$ However, additional measurements of these administrative costs are required. In Hungary, which is an upper-middle income country, the costs of administering local taxes represent less than 10 percent (between 2.8 to 8.7 percent) of total tax revenues (Garzon 2004).
} 


\section{References}

Ahmad, E. (1997). “Intergovernmental Transfers - An International Perspective.” In E. Ahmad (ed.) Financing Decentralized Expenditures. An International Comparison of Grants. Cheltenham, Edward Elgar.

Alm, J. and J. Martinez-Vazquez (2001). "Institutions, Paradigms, and Tax Evasion in Developing and Transitional Countries.” Georgia, Georgia State University. (Paper prepared for: Public Finance in Developing and Transitional Countries: A Conference in Honor of Richard Bird)

Alsop, R. et al. (2002). “Community-Level User Groups in Three World Bank-Aided Projects. Do They Perform as Expected?” Washington, The World Bank. (Social Development Papers 40)

Alsop, R., A. Krishna, and. D. Sjoblom (2001) "Inclusion and Local Elected Governments: The Panchayat Raj System in India.” Washington, The World Bank (South Asia - Social Development Unit).

Alsop, R. and B. Kurey (2004). "Empowerment in Ethiopia. A Status Review.” Washington, The World Bank. (Draft)

Alsop, R. and N. Heinsohn (2005). "Measuring Empowerment in Practice: Structuring Analysis and Framing Indicators.” Washington, The World Bank. (Policy Research Working Papers 3510)

Bahl, R. (2001). "Property Taxation in Developing Countries: As Assessment in 2001.” Cambridge MA, Lincoln Institute of Land Policy. (Conference handout. October 23)

Bahl, R. and J. Linn (1992). Urban Public Finance in Developing Countries. Oxford, OUP/The World Bank.

Bahl, R. and L. Schroeder (1983). “Intergovernmental Fiscal Relations.” In R. Bahl and B. Miller (eds.) Local Government Finance in the Third World. A Case Study of the Pihllipines. USA, PRAEGER.

Baiocchi, G., P. Heller, and S. Chauduri (2004). "Evaluating Empowerment: Participatory Budgeting in Brazilian Municipalities.” Washington, The World Bank. (Draft)

Bird, R. (2000). "Intergovernmental Fiscal Relations in Latin America: Policy Design and Policy Outcomes.” Washington, Inter-American Development Bank. 
Bird, R. and F. Vaillancourt (1998). "Fiscal decentralization in developing countries: an overview.” In R. Bird and F. Vaillancourt (eds.) Fiscal Decentralization in Developing Countries. Cambridge, CUP.

Blair, H. (2000). "Participation and Accountability at the Periphery: Democratic Local Governance in Six Countries.” World Development 28(1): 21-39.

Burki, S., G. Perry, and W. Dillinger (1999). Beyond the Center: Decentralizing the State. Washington, The World Bank.

Brautigam, D. (2002). “Building Leviathan: Revenue, State Capacity and Governance.” IDS Bulletin 33(3): 10-20.

Devas, N. (2002). "Issues in Fiscal Decentralisation: Ensuring Resources Reach the Poor at the Point of Service Delivery.” UK, University of Birmingham. (Workshop on Improving Service Delivery in Developing Countries, November 24-30)

DFID (2002). “Local Government Decision-Making: Citizen Participation and Local Accountability. Examples of Good (and Bad) Practice in Kenya.” UK, University of Birmingham.

Ebel, R. and F. Vaillancourt (2001). "Fiscal Decentralization and Financing Urban Governments: Framing the Problem.” In M. Freire and R. Stern (eds.) The Challenges of Urban Government. Policies and Practices. Washington, The World Bank Institute/University of Toronto.

Fjeldstad, O. (2002). "Collectors, Councillors and Donors: Local Government Taxation and State-Society Relations in Tanzania.” IDS Bulletin 33(3): 21-29.

Fox, J. and J. Aranda (1996). "Decentralization and Rural Development in Mexico. Community Participation in Oaxaca's Municipal Funds Program." San Diego, Center for U.S.-Mexican Studies.

Gaventa, J. and C. Valderrama (1999). "Participation, Citizenship and Local Governance.” UK, IDS. (Background note prepared for workshop on Strengthening Participation in Local Governance)

Garzon, H. (2004). "Local Revenues in Selected Municipalities." In M. Kopanyi, D. Wetzel and S. El Daher (eds.) Intergovernmental Finance in Hungary. A Decade of Experience 1990-2000. Washington, The World Bank.

Gloppen, S. and L. Rakner (2002). “Accountability through Tax Reform.” IDS Bulletin 33(3): 30-40.

Govender, R. (2003). "Review of Political and Administrative Accountability in Two Woredas and Two Municipalities in Ethiopia.” South Africa (Report prepared for The World Bank Country Office -Ethiopia) 
Guyer, J. (1992). "Representation without Taxation: An Essay on Democracy in Rural Nigeria, 1952-1990.” African Studies Review 35(1): 41-79.

Hansohm, D. et al. (2002). “Taxation, Expenditure and Accountability: Lessons from Namibia.” IDS Bulletin 33(3): 58-66.

Heymans, C. and M. Mussa (2004). "Intergovernmental Fiscal Reforms in Ethiopia: Trends and Issues.” Washington, The World Bank. (Draft)

Hood, C. (1986). “Privatizing UK Tax Law Enforcement.” Public Administration 64: 319-333.

Inter-American Development Bank (1994). Economic and Social Progress in Latin America. Fiscal Decentralization: The Search for Equity and Efficiency. Washington, The Johns Hopkins University Press.

Jones, G. and J. Stewart (1983). The Case for Local Government. London, Allen \& Unwin.

Jutting, J. et al. (2004). "Decentralisation and Poverty in Developing Countries: Exploring the Impact.” Paris, OECD. (OECD Development Centre Working Paper 236)

Keenan, A. and P. Dean (1980) “Moral Evaluation of Tax Evasion.” Social Policy \& Administration, 14(3): 209-220.

Levi, M. (1988). Of Rule and Revenue. Berkeley, University of California Press.

Litvack, J., J. Ahmad, and R. Bird (1998). "Rethinking Decentralization in Developing Countries.” Washington, The World Bank.

Luoga, F. (2002). “Taxpayers' Rights in the Context of Democratic Governance.” IDS Bulletin 33(3): 50-57.

Mansuri, G. and V. Rao (2004). Community-Based and -Driven Development: A critical Review. Washington, DC, The World Bank. (Policy Research Working Paper 3209)

Margolis, H. (1991) "Incomplete Coercion: How Social Preferences Mix with Private Preferences,” in K. Monroe (ed.) An Economic Approach to Politics. New York, Harper and Row.

McLure, Charles (2001). "The Tax Assignment Problem: Ruminations on How Theory and Practice Depend on History.” National Tax Journal LIV(2): 339-361.

Merat, J. (2004). "Taxation and Local Government Accountability in a Clientelist Context: Colombia." Public Administration and Development 24: 247-254. 
Moore, M. (1998). “Death without Taxes.” In M. Robinson and G. White (eds.) The democratic developmental state: politics and institutional design. New York, OUP.

Moore, M. (2001). “Political Underdevelopment. What causes 'bad governance'.” Public Management Review 3(3): 385-418.

Moore, M. and L. Rakner (2002). "Introduction: The New Politics of Taxation and Accountability in Developing Countries.” IDS Bulletin 33(3): 1-9.

Norregaard, J. (1997). “Tax assignment.” In T. Ter-Minassian (ed.) Fiscal Federalism in Theory and Practice. Washington, IMF.

Oates, W. (1999). “An Essay on Fiscal Federalism.” Journal of Economic Literature XXXVII(3): 1120-49.

Pineda, C. (Octubre 2003). "Condiciones del marco nacional para los procesos de preparación participativa de presupuestos municipales en Nicaragua.” Managua, Informe de Trabajo para el Instituto del Banco Mundial.

Peterson, G. (2000). Building Local Credit Systems. Washington, The World Bank.

Rajaraman, I. and G. Vasishtha (2000). "Impact of Grants on Tax Effort of Local Government.” Economic and Political Weekly.

Rao, G., R. Bird, and J. Litvack (1998). "Fiscal Decentralization and Poverty Alleviation in a Transitional Economy: The Case if Viet Nam.” Asian Economic Journal 12(4): 353-378.

Shah, A. (1994). "The Reform of Intergovernmental Fiscal Relations in Developing and Emerging Market Economies.” Washington, The World Bank.

Shah, A. (1998). "Fostering fiscally responsive and accountable governance: lessons from decentralization.” In R. Picciotto and E. Wiesner (eds.) Evaluation and Development. The Institutional Dimension. Washington, The World Bank.

Shah, A. (2004). "Fiscal Decentralization in Developing and Transitional Economies." Washington, The World Bank. (Policy Research Working Paper 3282)

Shah, A. and T. Thompson (2004). "Implementing Decentralized Local Governance: A Treacherous Road with Potholes, Detours and Road Closures.” Washington, The World Bank. (Policy Research Working Paper 3353)

Schneider, A. (2003). "Who gets what from whom? The impact of decentralisation on tax capacity and pro-poor policy.” Sussex, UK, IDS.

Souza, C. (2001). "Participatory Budgeting in Brazilian Cities: Limits and Possibilities in 
Building Democratic Institutions.”

Tanzi, V. (2004). "Measuring Efficiency in Public Expenditure.” Washington, The World Bank. (Paper prepared for the conference on Public Expenditure Efficiency and Growth, October 27)

Ter-Minassian, T. (1997). "Intergovernmental Fiscal Relations in a Macroeconomic Perspective: An Overview.” In T. Ter-Minassian (ed.) Fiscal Federalism in Theory and Practice. Washington, IMF.

The Center of Mongol Management (2004). “A Research Report on Fiscal Decentralization.” Ulaanbaatar, CMM. (Draft)

The World Bank (2001). “Ethiopia. Woreda Study (Volume 1).” Washington.

The World Bank (2003). "Making Services Work for Poor People -The Role of Participatory Public Expenditure Management.” Washington (Social Development Notes 81)

The World Bank (2004). “Ethiopia. Public Expenditure Review.” Washington.

The World Bank (2004a). "India. Fiscal Decentralization to Rural Governments.” Washington.

The World Bank (2004b). "Local Organizations for Decentralized Development in India. Sector Summary Paper.” Washington.

The World Bank (2004c). "Local Organizations in Nepal. A five sector study of district and sub-district organizations." SASES-Research Report. Washington.

The World Bank (2004d). "Mongolia. Sustainable Livelihoods Program 5th Supervision Mission. Fiscal Decentralization Component.” (Draft - Internal Document).

The World Bank Institute (2003). "Participación Cívica en la Preparación de Presupuestos Subnacionales. Sistematización de estudios de caso nacionales y subnacionales realizados en América Latina.” (http://vle.worldbank.org/gdlnscripts/dlmanage.exe)

Von Braun, J. and U. Grote (2000). “Does Decentralization Serve the Poor.” Washington, IMF. (Conference on fiscal decentralization) 


\section{Annex 1. Case Study: Starving Good Governance to feed the Needy (Extracts from Govender, 2003)}

Like many woredas in the southern part of Ethiopia, Alaba has been subject to great difficulties in recent times due to climate and market factors. Prompted by the October 2002 pre-harvest assessment report, the regional government undertook an initiative to distribute the General Food Rations (GFR) in March 2003. Using the Federal Disaster Preparedness and Prevention Office (DPPO) protocols, Alaba conducted a needs assessment and identified a list of beneficiaries in the woreda.

In July 2003, various quarters, both within and outside the woreda, expressed concern that something was amiss with the food distribution process. Local officials flagged the issue based on input from kebele leaders, who indicated increasing disquiet in their communities about the targeting of food aid.

To understand the root of the problem, a closer examination of the emergency food distribution process is needed. First, the DPPO undertakes initial assessments to flag emerging crises in woredas. If it is deemed that a woreda is in need of GFR, a beneficiary list within woredas is devised. The selection/identification of beneficiaries is conducted via a selection committee established at every kebele. The selection committee comprises the kebele chairperson and six members elected directly by the community to represent various constituencies such as women, youth, religious organizations, etc. These seven members then undertake their own assessment and determine a kebele list which is provided to the DPPC at woreda level, which then compiles this into a woreda list for submission to the regional office. The regional office determines the appropriateness of the beneficiary list, revises it arbitrarily, and sends it back to woreda, which then scales down its own list to adjust to the reduced quantity of GFR made available.

Two issues are important here. First, the selection committees at kebele level are established in accordance with federal government guidelines. There is a strong need to ensure the reduction/elimination of patronage and nepotism in food distribution, and thus, a distinct structure from the kebele council is established. The purpose is to improve targeting of the needy. In the case of Alaba, this mechanism seems to have failed entirely. Not only is the quota of food (incorrectly) based on the size of kebele population rather than those who need it most, but the redistribution process (after official distributions) indicates that patronage and nepotism are in all probability very much in existence. Second, food distribution is largely seen as being within the jurisdiction of the DPPO. Thus there is no attempt to involve the structures of governance that exist in the woreda, neither in terms of interacting with communities nor in terms of resolving emerging disputes and conflicts that result from deficient targeting methodologies and weak distribution logistics. This is a classic case of top down, externally driven parallel systems that prevent the development of local government capacity to fulfill legitimate mandates. 
The woreda council interviewed in this assessment seemed the most poorly informed among interviewees about the distribution of food in the woreda. This is largely because they had no contact whatsoever on this matter with either the regional government or with the NGO responsible for the actual distribution. Nevertheless, the woreda council was directly affected by the process, both in terms of having to give up their assembly room for the storage of food and in having to contend with the fallout of the poor targeting and distribution process. While the council is nominally considered an oversight mechanism for beneficiary selection, its role was limited as no-one knew the beneficiary list was deficient. However, the disempowerment of the council was most pronounced with regard to the actual food distribution process, where they were considered to have no role whatsoever by either the DPPO or the NGO. Despite this impotence, they were expected to manage the fallout and answer to the communities for the entire process of selection and distribution. This was evidenced by the need to undertake conflict resolution in kebeles where frustration had spilled over into violence. Moreover, they were required to do so without being able to rely on their existing structures of representation, this being the kebele council. Instead they relied on consultation with the selection committee, which by design required no accountability to the council.

Hence the ineffective approach to food aid in the woreda had implications not only for the hungry and needy, but also for the governance structures of the local jurisdiction. The sidestepping of the kebele council in the selection process, while perhaps well intentioned, effectively undermined the credibility of a governance structure. Also, the exclusion of the woreda council from oversight of both selection and distribution undermined the structure and its raison d'etre. Responsibility for this rested solely with the DPPO and the NGO, neither one of which was in any way accountable to the woreda electorate. Thus, the council was effectively sidelined.

As a result of all this, elected officials were held responsible for a process over which they were not even consulted, much less a process in which they participated. According to the peasant associations, community members blame the government for the mess, and are unlikely to distinguish between regional and woreda government in this assessment. In effect, they see this failure as an inability of their elected representatives to champion their needs and interests.

For the sake of balancing upward with downward accountability, the current distribution of food aid in Alaba holds valuable lessons not just for the provision of short term relief, but also for the establishment and growth of proper political governance and administrative accountability at the local jurisdiction level. 